\title{
Evaluation of ensiled soy sauce by-product combined with several additives as an animal feed
}

\author{
Sadarman Sadarman ${ }^{1,2}$, Muhammad Ridla ${ }^{3}$, Nahrowi Nahrowi ${ }^{3}$, Roni Ridwan ${ }^{4}$ (iD and Anuraga Jayanegara3 ${ }^{3}$ \\ 1. Study Program of Nutrition and Feed Science, Graduate School of IPB University, Bogor, Indonesia; 2. Department \\ of Animal Science, Sultan Syarif Kasim State Islamic University, Pekanbaru, Indonesia; 3. Department of Nutrition and \\ Feed Technology, Faculty of Animal Science, IPB University, Bogor, Indonesia; 4. Research Center for Biotechnology, \\ Indonesian Institute of Sciences, Cibinong, Indonesia. \\ Corresponding author: Anuraga Jayanegara, e-mail: anuraga.jayanegara@gmail.com \\ Co-authors: SS: sadarman@uin-suska.ac.id, MR: hmridla@yahoo.com, NN: nahrowi2504@yahoo.com, \\ RR: rony_biotech@yahoo.com \\ Received: 21-11-2019, Accepted: 15-04-2020, Published online: 19-05-2020
}

doi: www.doi.org/10.14202/vetworld.2020.940-946 How to cite this article: Sadarman S, Ridla M, Nahrowi N, Ridwan R, Jayanegara A (2020) Evaluation of ensiled soy sauce by-product combined with several additives as an animal feed, Veterinary World, 13(5): 940-946.

\begin{abstract}
Aim: The present experiment aimed to evaluate the use of different additives, i.e., lactic acid bacteria (LAB) inoculant, tannin extract, and propionic acid, on the chemical composition, fermentative characteristics, and in vitro ruminal fermentation of soy sauce by-product ( $\mathrm{SSB})$ silage.

Materials and Methods: SSB was subjected to seven silage additive treatments: Fresh SSB, ensiled SSB, ensiled SSB+LAB, ensiled $\mathrm{SSB}+2 \%$ acacia tannin, ensiled $\mathrm{SSB}+2 \%$ chestnut tannin, ensiled $\mathrm{SSB}+0.5 \%$ propionic acid, and ensiled $\mathrm{SSB}+1 \%$ acacia tannin $+1 \%$ chestnut tannin $+0.5 \%$ propionic acid. Ensiling was performed for 30 days in three replicates, and each replicate was made in duplicate. The samples were evaluated for their chemical composition and silage fermentation characteristics and were tested in an in vitro rumen fermentation system.
\end{abstract}

Results: In general, the nutrient compositions did not differ among the tested SSBs in response to the different additives used. The addition of tannins, either acacia or chestnut, and propionic acid significantly decreased the $\mathrm{pH}$ of the ensiled SSB $(p<0.05)$. The addition of several additives (except LAB) decreased the ammonia concentration in SSB silage ( $p<0.05)$. The total volatile fatty acids in the in vitro rumen fermentation profile of the ensiled SSB were not significantly altered by the various additives applied. The addition of some additives, i.e., ensiled SSB+LAB and ensiled SSB $+2 \%$ acacia tannin, reduced the digestibility values of the SSB $(p<0.05)$. Different silage additives did not significantly affect methane production, although the addition of acacia tannins tended to result in the lowest methane production among treatments.

Conclusion: The use of additives, particularly $2 \%$ acacia tannins, can reduce proteolysis in SSB silage.

Keywords: additive, feed, silage, soy sauce, tannins.

\section{Introduction}

There are many underutilized agro-industrial by-products that have the potential for use as animal feeds. One such agro-industrial by-product, soy sauce by-product (SSB), may cause environmental pollution when it is not managed properly [1]. SSB has been reported to contain relatively rich nutrients required by livestock [2]. However, its moisture content is high, which may induce rapid deterioration of the by-product. The conservation of such material is, therefore, necessary to prevent spoilage and to maintain the nutritional quality [3]. Ensiling is a wet preservation technique that is commonly applied in various feed materials. This technique can even improve the digestibility of feed materials by reducing anti-nutritional factors

Copyright: Sadarman, et al. Open Access. This article is distributed under the terms of the Creative Commons Attribution 4.0 International License (http://creativecommons.org/licenses/ by/4.0/), which permits unrestricted use, distribution, and reproduction in any medium, provided you give appropriate credit to the original author(s) and the source, provide a link to the Creative Commons license, and indicate if changes were made. The Creative Commons Public Domain Dedication waiver (http:// creativecommons.org/publicdomain/zero/1.0/) applies to the data made available in this article, unless otherwise stated. such as trypsin inhibitor [4,5]. Although drying is also a possible technique for preserving SSB, it requires sufficient solar radiation (for sun drying) that might not be achievable during the rainy season or the use of a sophisticated drying facility (for artificial drying).

Soy sauce is characterized by a high-protein content and thus is susceptible to protein degradation and deamination during the silage making process $[6,7]$. Protein protection in silage is required to maintain protein quality, particularly in high-protein silage such as legume silage and total mixed ration silage. Tannins are a naturally occurring polyphenol that have the ability to interact with other molecules, particularly protein, due to the presence of hydroxyl groups in their structure [8]. A previous study reported that tannin extract from chestnuts could inhibit proteolysis in Moringa and Indigofera leaf silages, as indicated by the lower ammonia $\left(\mathrm{NH}_{3}\right)$ concentration [9]. Furthermore, a meta-analysis revealed that higher tannin levels in the ensiled material resulted in lower $\mathrm{NH}_{3}$ and butyrate concentrations [10], indicating its potential application as a silage additive. Other additives that are commonly used for ensuring good quality silage are lactic acid bacteria 
(LAB) inoculant $[11,12]$ and various organic acids such as propionic acid [13] and formic acid [14,15].

The present experiment aimed to evaluate the use of different additives, i.e., LAB inoculant, tannin extract, and propionic acid, on the chemical composition, fermentative characteristics, and in vitro ruminal fermentation of SSB silage.

\section{Materials and Methods}

\section{Ethical approval}

The source of microbial inoculum in this study was rumen fluid that contained solid particles. The rumen fluid was obtained from two fistulated Ongole crossbred bulls before morning feeding time at the Biotechnology Research Center, Indonesian Institute of Sciences, Bogor, Indonesia. The bulls were maintained in accordance with the animal welfare standards of the Indonesian Institute of Sciences. All protocols were approved by the Faculty of Animal Science, Bogor Agricultural University, Indonesia.

\section{Sample collection and ensiling procedure}

This experiment was carried out from September 2019 to February 2020. The SSB was obtained from a company called PT Zebra Bogor, which is located in Cihideung Ilir, Ciampea district, Bogor Regency, West Java Province. A sample of $20 \mathrm{~kg}$ (wet basis) was freshly collected and then immediately processed for the ensiling procedure. Acacia bark was obtained from PT Indonesia Fiberboard, Musi Banyuasin Regency, Palembang. The bark was a by-product from the processing of acacia trees for making paper. A total of $50 \mathrm{~kg}$ of acacia bark was freshly collected and subsequently transported to the laboratory for further processing. Tannins were extracted from the bark using a hot water extraction system at $120^{\circ} \mathrm{C}, 200 \mathrm{kPa}$ for $3 \mathrm{~h}$. The water was subsequently evaporated in an oven at $50^{\circ} \mathrm{C}$ for $24 \mathrm{~h}$ to obtain tannin powder. The ensiling procedure was performed according to the method of Kondo et al. [3] for 30 days. The fresh SSB was weighed, placed on a tray, combined with additives according to the experimental treatments, mixed thoroughly, and stored in a laboratory scale silo. The silo was tightly closed to maintain an anaerobic condition and was placed at room temperature $\left(25-27^{\circ} \mathrm{C}\right)$ without any direct sunlight exposure.

\section{In vitro incubation}

After being ensiled, the fermented SSB was dried at $50^{\circ} \mathrm{C}$ for $24 \mathrm{~h}$ and ground by a hammer mill to pass through a $1 \mathrm{~mm}$ sieve size. All ground samples were incubated in vitro with buffered rumen fluid in serum bottles (125 ml capacity) [16]. Each bottle was filled with $500 \mathrm{mg}$ of SSB (dry matter [DM] basis), $17 \mathrm{ml}$ of rumen liquid, and $33 \mathrm{ml}$ of buffer. Before use, freshly collected rumen liquid was filtered with a nylon filter cloth $(100 \mu \mathrm{m}$ sieve size) and then added to the buffer. The rumen buffer solution was saturated with $\mathrm{CO}_{2}$ gas for $10 \mathrm{~min}$ and subsequently placed into the serum bottle. The incubation bottle was immediately closed and then transferred to a water bath with a temperature of $39^{\circ} \mathrm{C}$ for $24 \mathrm{~h}$.

\section{Observed variables}

The observed variables included the chemical composition of the fermented SSB (organic matter, ash, crude protein, ether extract, neutral detergent fiber (NDF), and acid detergent fiber [ADF]), the fermentation profiles of the SSB silage $\left(\mathrm{pH}, \mathrm{NH}_{3}\right.$, total volatile fatty acid [VFA], and LAB population), and the in vitro rumen fermentation characteristics (total VFA, $\mathrm{NH}_{3}$, DM digestibility, organic matter digestibility, gas production, and methane). Organic matter, ash, crude protein, and ether extract contents were determined according to the AOAC [17], whereas the NDF and ADF contents were analyzed according to the method of Van Soest et al. [18]. These analyses were performed in duplicate from pooled samples, and the data were presented descriptively. The $\mathrm{pH}$ of silage was measured using a $\mathrm{pH}$ meter, whereas the $\mathrm{NH}_{3}$ and total VFA concentrations were determined by Conway microdiffusion and steam distillation methods, respectively [19]. The LAB population was determined by the total plate count method [20]. Gas production was observed $24 \mathrm{~h}$ after incubation using a $50 \mathrm{ml}$ gas syringe equipped with a needle. The methane concentration was measured by injecting the gas into a gas chromatograph (Shimadzu 8A GC, Shimadzu Corp., Kyoto, Japan) equipped with a flame ionization detector [21]. To determine digestibility, the samples were further incubated with pepsin- $\mathrm{HCl}$ at $39^{\circ} \mathrm{C}$ for another $24 \mathrm{~h} \mathrm{[22].} \mathrm{The} \mathrm{residue} \mathrm{was} \mathrm{filtered}$ and dried in an oven at $105^{\circ} \mathrm{C}$ for $24 \mathrm{~h}$. Digestibility was calculated by subtracting the residue from the initial amount of sample, corrected according to the blank sample.

\section{Experimental design}

The SSB was subjected to seven silage additive treatments: Fresh SSB, ensiled SSB, ensiled $\mathrm{SSB}+\mathrm{LAB}$, ensiled $\mathrm{SSB}+2 \%$ acacia tannin, ensiled $\mathrm{SSB}+2 \%$ chestnut tannin, ensiled $\mathrm{SSB}+0.5 \%$ propionic acid, and ensiled $\mathrm{SSB}+1 \%$ acacia tannin $+1 \%$ chestnut tannin $+0.5 \%$ propionic acid. The allocation of the treatments into experimental units followed a randomized complete block design with three replications (each was performed in duplicate) for each treatment. Different experimental runs that were performed during different weeks served as the blocks. There were a total of 42 samples (treatment $\times$ block/replicate $\times$ duplicate).

\section{Statistical analysis}

The data were analyzed with an analysis of variance using IBM SPSS software version 23 (IBM Corp., New York, USA). Duncan's test was performed for any variables that showed significance at $\mathrm{p}<0.05$ for comparisons among different treatment means.

\section{Results and Discussion}

Nutrient composition and fermentation characteristics of ensiled SSB

The crude protein content of fresh SSB in the present experiment was slightly above 30\% DM 
(Table-1). This value was comparable to that reported in the study of Uddin et al. [23] and higher than that of Yasuda et al. [24] who reported CP values of 31.0\% and $26.6 \% \mathrm{DM}$ for SSB, respectively. In general, the ensiling treatments with different additives did not alter the nutrient contents of the SSB. The similarity of the nutrient composition might be caused by the similar raw materials used. In some cases, the difference in raw materials might cause the variations in silage quality. Silage that originates from a raw material with a high-protein content typically has a lower quality than that originating from a raw material with a low-protein content because of its high buffering capacity. For example, it is relatively difficult to ensile legumes and their by-products because of their high-protein contents [25]. In the present experiment, the CP contents of all tested SSBs were comparable, i.e. slightly above $29 \% \mathrm{DM}$ in response to the different additives applied. The SSB, therefore, showed its potency to be a protein supplement in animal diets. The previous studies have reported the use of Indigofera and Moringa silages as ruminant diets because of their high CP [26,27], and the CP of the SSB in the present study was comparable to those feed ingredients. Ensiling (without any additives) apparently did not change the NDF and ADF contents

Table-1: Nutrient composition of ensiled SSB treated with various additives (\% DM).

\begin{tabular}{lcccccc}
\hline \multirow{2}{*}{ Treatment } & \multicolumn{6}{c}{ Variable } \\
\cline { 2 - 7 } & OM & Ash & CP & EE & NDF & ADF \\
\hline R0 & 74.5 & 25.5 & 30.8 & 15.6 & 35.5 & 23.3 \\
R1 & 78.0 & 22.0 & 31.2 & 16.7 & 35.6 & 19.6 \\
R2 & 79.3 & 20.7 & 29.8 & 16.5 & 28.0 & 20.5 \\
R3 & 77.0 & 23.0 & 31.8 & 14.7 & 28.8 & 17.0 \\
R4 & 77.9 & 22.1 & 29.9 & 18.6 & 27.6 & 23.2 \\
R5 & 77.2 & 22.8 & 29.8 & 17.9 & 25.3 & 21.4 \\
R6 & 79.3 & 20.7 & 29.6 & 23.2 & 34.2 & 22.6 \\
\hline
\end{tabular}

$\mathrm{OM}=$ Organic matter, $\mathrm{CP}=$ Crude protein, $\mathrm{EE}=$ Ether extract, $\mathrm{NDF}=$ Neutral detergent fiber, $A D F=$ Acid detergent fiber, $\mathrm{SSB}=$ Soy sauce by-product, $\mathrm{R} 0=$ fresh $\mathrm{SSB}, \mathrm{R} 1=$ Ensiled SSB, R2 = Ensiled SSB+lactic acid bacteria, R3=Ensiled $\mathrm{SSB}+2 \%$ acacia tannin, R4=Ensiled SSB $+2 \%$ chestnut tannin; R5=Ensiled SSB+0.5\% propionic acid, R6=Ensiled SSB $+1 \%$ acacia tannin $+1 \%$ chestnut tannin $+0.5 \%$ propionic acid of SSB. Furthermore, the addition of tannins did not alter the NDF and ADF contents, which has also been reported by other studies [28,29]. Such unchanged NDF and ADF contents in silage indicate the lower affinity of tannins on fiber components compared to protein [9].

The $\mathrm{pH}$ in the ensiled SSB was significantly affected by different additives (Table-2). The highest $\mathrm{pH}$ was found in the ensiled SSB without any additives, and it was not significantly different than ensiled SSB+LAB. The addition of tannins, either acacia or chestnut, and propionic acid significantly decreased the $\mathrm{pH}$ of the ensiled SSB $(\mathrm{p}<0.05)$. The lower $\mathrm{pH}$ condition was apparently caused by the increased lactic acid concentration as a result of more water soluble and fermentable carbohydrates. Several bacteria proliferated and used those carbohydrates to generate lactic acid [30]. As more lactic acid is produced, the $\mathrm{pH}$ decreases to a greater degree, leading to the growth inhibition of undesired microbes [31]. The addition of appropriate additives to the ensiled SSB is necessary to obtain a higher $\mathrm{pH}$ than that of grass [32]. The $\mathrm{pH}$ of grass originated silage is approximately 4.0 or lower $[29,33]$, whereas the $\mathrm{pH}$ of SSB in the present study was above 5 . A previous study stated that it is difficult to obtain a $\mathrm{pH}$ of less than 4.5 with legume originated silage [34]. The silage temperature did not differ much among the treatments and ranged from 28.9 to $29.4^{\circ} \mathrm{C}$.

The addition of several additives (except LAB only) decreased the $\mathrm{NH}_{3}$ concentration in the SSB silage $\left(\mathrm{p}<0.05\right.$; Table-2). The lowest $\mathrm{NH}_{3}$ concentration was found in the ensiled $\mathrm{SSB}+2 \%$ chestnut tannin, but the concentration did not differ significantly compared with that of ensiled $\mathrm{SSB}+2 \%$ acacia tannin. The decrease in $\mathrm{NH}_{3}$ indicated the potency to preserve the SSB protein. During the ensiling process, extensive protein degradation and deamination occur that could lower the protein quality of the feed material [32]. The presence of tannins could protect the protein inside the raw material from microbial degradation. Tannins are composed of free phenolic groups that could generate tannin-protein complexes [35]. Tannins could also impede the activity of proteolytic microbes because

Table-2: Fermentation characteristics of ensiled SSB treated with various additives.

\begin{tabular}{|c|c|c|c|c|}
\hline \multirow[t]{2}{*}{ Treatment } & \multicolumn{4}{|c|}{ Variable } \\
\hline & pH & $\mathrm{NH}_{3}(\mathrm{mmol} / \mathrm{I})$ & Total VFA ( $\mathrm{mmol} / \mathrm{I})$ & LAB $(\log \mathrm{cfu} / \mathrm{ml})$ \\
\hline $\mathrm{R} 1$ & $6.32 \pm 0.09^{c}$ & $5.13 \pm 0.29^{c}$ & $46.8 \pm 7.65^{\mathrm{ab}}$ & $6.83 \pm 0.23$ \\
\hline $\mathrm{R} 2$ & $6.40 \pm 0.10^{c}$ & $8.67 \pm 0.59^{d}$ & $68.5 \pm 5.79^{c d}$ & $6.07 \pm 0.42$ \\
\hline R3 & $6.05 \pm 0.07^{b}$ & $2.61 \pm 0.28^{a}$ & $38.4 \pm 12.61^{a}$ & $6.23 \pm 0.46$ \\
\hline R4 & $5.88 \pm 0.02^{a}$ & $2.93 \pm 0.44^{a}$ & $58.5 \pm 7.65^{\mathrm{bc}}$ & $5.79 \pm 0.36$ \\
\hline R5 & $5.90 \pm 0.03^{a}$ & $5.23 \pm 0.49^{c}$ & $71.8 \pm 2.89^{d}$ & $5.83 \pm 0.14$ \\
\hline R6 & $5.87 \pm 0.03^{a}$ & $4.08 \pm 0.16^{b}$ & $48.4 \pm 5.79^{a b}$ & $5.91 \pm 0.55$ \\
\hline p-value & $<0.001$ & $<0.001$ & $<0.001$ & 0.070 \\
\hline
\end{tabular}

Means with different superscripts within a column are significantly different $(p<0.05) . \mathrm{NH}_{3}=\mathrm{Ammonia}$, VFA $=$ Volatile fatty acid, LAB=Lactic acid bacteria, SSB=Soy sauce by-product, R1=Ensiled SSB; R2=Ensiled SSB+lactic acid bacteria, $\mathrm{R} 3=$ Ensiled $\mathrm{SSB}+2 \%$ acacia tannin, $\mathrm{R} 4=$ Ensiled $\mathrm{SSB}+2 \%$ chestnut tannin; R5=Ensiled $\mathrm{SSB}+0.5 \%$ propionic acid, $\mathrm{R} 6=$ Ensiled $\mathrm{SSB}+1 \%$ acacia tannin $+1 \%$ chestnut tannin $+0.5 \%$ propionic acid 
they can bind to the specific site of the enzyme that is produced by its bacteria [28]. The reduction of $\mathrm{NH}_{3}$ as an effect of the tannin addition was also previously shown by Ding et al. [36] during the production of alfalfa silage. Thus, tannins could suppress protein degradation during ensiling, particularly in a high-protein silage such as SSB. The addition of $2 \%$ acacia tannins to ensiled SSB was also the only additive treatment that significantly decreased the VFA concentration compared to the original ensiled SSB. This finding was in agreement with a previous study that described the production of Indigofera and Moringa silages [9]. Such lower $\mathrm{NH}_{3}$ concentrations in silage are associated with a lower $\mathrm{pH}$, as demonstrated in the present experiment. $\mathrm{NH}_{3}$ is considered an alkali and therefore its concentration is positively correlated with silage $\mathrm{pH}$.

\section{In vitro rumen fermentation profiles and digestibility of ensiled SSB}

The total VFA in the in vitro rumen fermentation profile of the ensiled SSB was not significantly altered by the various additives applied (Table-3). VFA is a fermentation product of carbohydrate [37] that provides more than $70 \%$ of the energy supply for the ruminant [38]. Three main VFAs are produced in the rumen: Acetic acid, propionic acid, and butyric acid [38]. The in vitro rumen fermentation profile from forages with high-fiber contents could produce high acetic and butyric acid contents, whereas those from concentrated feed material could produce high propionic acid contents [39-41]. A previous study reported that the total VFA depended on the concentration of tannins used and the species of crop that produced the tannins $[42,43]$. There was no significant effect of several additives on the ensiled SSB in terms of the $\mathrm{NH}_{3}$ concentration (Table-3). However, the variations in $\mathrm{NH}_{3}$ concentrations observed in this study were within the normal range. The normal $\mathrm{NH}_{3}$ concentration in the rumen ranges between 6 and $21 \mathrm{mmol} / 1$ [38].

The in vitro DM digestibility (IVDMD) and in vitro organic matter digestibility (IVOMD) of all tested SSBs were significantly affected by the addition of various additives (Table- 3 ). The addition of some additives reduced the IVDMD and IVOMD values of the SSB, i.e. ensiled SSB+LAB and ensiled $\mathrm{SSB}+2 \%$ acacia tannin $(\mathrm{p}<0.05)$. The previous findings reported that the addition of tannins reduced the in vitro digestibility of feed materials [44-46]. The reduction of those variables indicated the decrease in nutrient degradation, particularly protein and fiber, since tannins can form complexes with these macronutrients to decelerate their degradation by rumen microbes $[8,35]$. Such tannin-protein interactions may strategically be used to protect protein from ruminal degradation and enhance the proportion of protein bypass. If the complex is released in the abomasum due to the low $\mathrm{pH}$, protein may then be digested in the small intestine and contribute to the higher metabolizable protein supply for the ruminant livestock [47]. This phenomenon explains the enhancement of milk production and daily gain of dairy cows and beef cattle, respectively, when the animals are administered tannins at an appropriate concentration.

The production of gas and methane in the in vitro rumen fermentation of SSB is shown in Table-4. There were no differences in the gas production between fresh SSB and original ensiled SSB (without any additive). However, there was a significant decrease of gas production in the ensiled $\mathrm{SSB}+2 \%$ acacia tannin, the ensiled $\mathrm{SSB}+0.5 \%$ propionic acid, and the ensiled $\mathrm{SSB}+1 \%$ acacia tannin $+1 \%$ chestnut tannin $+0.5 \%$ propionic acid compared to fresh SSB $(p<0.05)$. The lowest gas production was observed in the treatment of ensiled SSB $+2 \%$ acacia tannin. This finding was supported by a previous study that used $1-2 \%$ tannin additive on SSB [2]. The gas produced during rumen fermentation is an important variable to evaluate because it could indicate the quantity and proportion of feed consumed by livestock $[25,38]$. The gas is generated by the process of nutrient degradation in the in vitro rumen fermentation system. Carbohydrates contribute the most to gas production, even though protein may also contribute to a lesser extent; fat does not contribute to gas production [48]. Thus, gas production is apparently associated with the carbohydrate contents of the substrate. A previous study showed a positive correlation between starch content and gas production [49].

Table-3: In vitro rumen fermentation profiles of ensiled SSB treated with various additives.

\begin{tabular}{|c|c|c|c|c|}
\hline \multirow[t]{2}{*}{ Treatment } & \multicolumn{4}{|c|}{ Variable } \\
\hline & Total VFA (mmol/I) & $\mathrm{NH}_{3}(\mathrm{mmol} / \mathrm{I})$ & IVDMD (\%) & IVOMD (\%) \\
\hline $\mathrm{RO}$ & $109 \pm 24.7$ & $16.8 \pm 2.74$ & $52.9 \pm 1.79^{c}$ & $51.3 \pm 1.79^{c}$ \\
\hline R1 & $121 \pm 14.0$ & $15.1 \pm 2.16$ & $51.0 \pm 1.95^{b c}$ & $49.5 \pm 1.94^{b c}$ \\
\hline $\mathrm{R} 2$ & $116 \pm 20.7$ & $17.0 \pm 4.51$ & $45.3 \pm 1.42^{a}$ & $43.8 \pm 1.43^{a}$ \\
\hline R3 & $131 \pm 20.9$ & $18.2 \pm 1.99$ & $49.1 \pm 2.59^{b}$ & $47.6 \pm 2.59^{b}$ \\
\hline $\mathrm{R} 4$ & $115 \pm 16.0$ & $13.5 \pm 2.32$ & $51.2 \pm 3.03^{b c}$ & $49.6 \pm 3.02^{b c}$ \\
\hline $\mathrm{R} 5$ & $125 \pm 27.4$ & $18.0 \pm 3.75$ & $52.0 \pm 2.09^{c}$ & $50.5 \pm 2.09^{c}$ \\
\hline R6 & $126 \pm 15.3$ & $18.1 \pm 1.46$ & $53.5 \pm 1.22^{c}$ & $52.0 \pm 1.22^{c}$ \\
\hline p-value & 0.520 & 0.370 & $<0.001$ & $<0.001$ \\
\hline
\end{tabular}

Means with different superscripts within a column are significantly different $(\mathrm{p}<0.05)$. VFA=Volatile fatty acid,

$\mathrm{NH}_{3}=$ Ammonia, IVDMD = In vitro dry matter digestibility, IVOMD=In vitro organic matter digestibility, $\mathrm{SSB}=\mathrm{Soy}$ sauce by-product, R0=Fresh SSB; R1=Ensiled SSB; R2=Ensiled SSB+lactic acid bacteria, R3=Ensiled SSB+2\% acacia tannin, $\mathrm{R} 4=$ Ensiled SSB $+2 \%$ chestnut tannin, R5=Ensiled SSB $+0.5 \%$ propionic acid, R6=Ensiled SSB $1 \%$ acacia tannin $+1 \%$ chestnut tannin $+0.5 \%$ propionic acid 
Table-4: The production of gas and methane $\left(\mathrm{CH}_{4}\right)$ in in vitro fermented rumen with various additive treatments.

\begin{tabular}{lcc}
\hline Treatments & \multicolumn{2}{c}{ Variable } \\
\cline { 2 - 3 } & Gas production (ml) & $\mathbf{C H}_{\mathbf{4}}$ (\% gas) \\
\hline R0 & $26.5 \pm 1.72^{\mathrm{ab}}$ & $2.07 \pm 0.40$ \\
R1 & $28.7 \pm 0.89^{\mathrm{b}}$ & $2.24 \pm 0.28$ \\
R2 & $28.5 \pm 2.48^{\mathrm{b}}$ & $2.26 \pm 0.45$ \\
R3 & $25.3 \pm 0.98^{\mathrm{a}}$ & $1.77 \pm 0.45$ \\
R4 & $27.0 \pm 0.82^{\mathrm{ab}}$ & $1.93 \pm 0.76$ \\
R5 & $25.8 \pm 1.94^{\mathrm{a}}$ & $1.81 \pm 0.77$ \\
R6 & $25.5 \pm 1.75^{\mathrm{a}}$ & $2.22 \pm 0.49$ \\
p-value & 0.010 & 0.370 \\
\hline
\end{tabular}

Means with different superscripts within a column are significantly different $(p<0.05) . R 0=$ Fresh $S S B$, $\mathrm{R} 1=$ Ensiled SSB, $\mathrm{R} 2=$ Ensiled SSB +lactic acid bacteria R3=Ensiled SSB $+2 \%$ acacia tannin, R4=Ensiled SSB+2\% chestnut tannin, $\mathrm{R} 5=$ Ensiled $\mathrm{SSB}+0.5 \%$ propionic acid, R6 $=$ Ensiled SSB $+1 \%$ acacia tannin $+1 \%$ chestnut tannin $+0.5 \%$ propionic acid

The use of different silage additives did not significantly affect methane production, although the use of acacia tannins tended to have the lowest methane production among the treatments (Table-4). Thus, acacia tannins have the potential to impede the growth of methane-forming microorganisms. A previous meta-analysis showed that tannins could reduce the absolute methane content in both in vitro and in vivo experiments [50]. Two types of tannins are commonly used to reduce methane: Hydrolysable tannins and condensed tannins [38]. Chestnut tannins mainly contain hydrolysable tannins, whereas acacia tannins are primarily comprised condensed tannins. The insignificant methane reduction on ensiled $\mathrm{SSB}+1 \%$ acacia $\operatorname{tannin}+1 \%$ chestnut tannin $+0.5 \%$ propionic acid is apparently associated with the low concentration of tannins used. The variation of $\mathrm{pH}$ values in silages has a minor influence on rumen fermentation parameters such as VFA, $\mathrm{NH}_{3}$, and methane in the in vitro system. A buffer is typically added in the in vitro rumen fermentation system at a certain amount to prevent $\mathrm{pH}$ changes so that rumen microbial activity and fermentation can be normally performed until the end of incubation [16].

\section{Conclusion}

The nutrient compositions did not differ among the tested SSBs in response to the different additives used. The addition of acacia tannins or chestnut tannins resulted in decreased $\mathrm{pH}$ and $\mathrm{NH}_{3}$ concentrations of the SSB silage, thus preserving the SSB during the fermentation process. A reduction of in vitro digestibility in the ensiled SSB was observed with the addition of $\mathrm{LAB}$ or acacia tannins. The addition of $2 \%$ acacia tannins could also reduce the gas production. In conclusion, the use of $2 \%$ acacia tannins is recommended for SSB ensiling.

\section{Authors' Contributions}

SS performed the experiment, collected the data, and drafted the manuscript. AJ designed and supervised the experiment, checked the data analysis, and revised the manuscript. MR, NN, and RR supervised the experiment and revised the manuscript. All authors read and approved the final manuscript.

\section{Acknowledgments}

This research was funded by Indonesian Ministry of Research, Technology, and Higher Education of Indonesia through "Hibah Penelitian Dasar Berbasis Kompetensi (HIKOM)," year 2019, contract number 3/E1/KP.PTNBH/2019.

\section{Competing Interests}

The authors declare that they have no competing interests.

\section{Publisher's Note}

Veterinary World remains neutral with regard to jurisdictional claims in published institutional affiliation.

\section{References}

1. Lv, S., Liang, Z., Li, X., Fan, H. and Zen, Y. (2016) Investigation on biomass performance of a submerged membrane bioreactor for treating soy sauce wastewater. Environ. Prot. Eng., 42(1): 135-148.

2. Sadarman, S., Ridla, M., Nahrowi, N., Sujarnoko, T.U.P., Ridwan, R. and Jayanegara, A. (2019) Evaluation of ration based on soy sauce by-product on addition of acacia and chestnut tannin: An in vitro study. IOP Conf. Ser. Mater. Sci. Eng., 546: 022020 .

3. Kondo, M., Shimizu, K., Jayanegara, A., Mishima, T., Matsui, H., Karita, S., Goto, M. and Fujihara, T. (2016) Changes in nutrient composition and in vitro ruminal fermentation of total mixed ration silage stored at different temperatures and periods. J. Sci. Food Agric., 96(4): $1175-1180$.

4. Liener, I. (1962) Toxic factors in edible legumes and their elimination. Am. J. Clin. Nutr., 1(1): 281-298.

5. Belmarl, R., Nava-Montero, R., Sandoval-Castro, C. and Mcnab, J. (1999) Jack bean (Canavalia ensiformis L. DC) in poultry diets: Antinutritional factors and detoxification studies-a review. Worlds Poult. Sci. J., 55(1): 37-59.

6. Owens, V.N., Albrecht, K.A., Muck, R.E. and Duke, S.H. (1999) Protein degradation and fermentation characteristics of red clover and alfalfa silage harvested with varying levels of total nonstructural carbohydrates. Crop Sci., 39(6): 1873-1880

7. Ke, W.C., Ding, W.R., Xu, D.M., Ding, L.M., Zhang, P., Li, F.D. and Guo, X.S. (2017) Effects of addition of malic or citric acids on fermentation quality and chemical characteristics of alfalfa silage. J. Dairy Sci., 100(11): 8958-8966.

8. Kondo, M., Hirano, Y., Ikai, N., Kita, K., Jayanegara, A. and Yokota, H.O. (2014) Assessment of anti-nutritive activity of tannins in tea by-products based on in vitro rumen fermentation. Asian Australas. J. Anim. Sci., 27(11): 1571-1576.

9. Jayanegara, A., Yaman, A. and Khotijah, L. (2019) Reduction of proteolysis of high protein silage from moringa and indigofera leaves by addition of tannin extract. Vet. World, 12(2): 211-217.

10. Jayanegara, A., Sujarnoko, T.U.P., Ridla, M., Kondo, M. and Kreuzer, M. (2019) Silage quality as influenced by concentration and type of tannins present in the material ensiled: A meta-analysis. J. Anim. Physiol. Anim. Nutr., 103(2): 456-465.

11. Winters, A.L., Cockburn, J.E., Dhanoa, M.S. and Merry, R.J. (2000) Effects of lactic acid bacteria in inoculants on changes in amino acid composition during ensilage 
of sterile and nonsterile ryegrass. J. Appl. Microbiol., 89(3): 442-451.

12. Jia, Y.F., Shi, W.Y., Wu, L.H. and Wang, H.L. (2011) Effects of ensilage on the preservation of bamboo shoot shells and their fibre characteristics. J. Trop. Forest Sci., 23(4): 396-403.

13. Chen, L., Guoa, G., Yuan, X., Shimojo, M., Yu, C. and Shao, T. (2014) Effect of applying molasses and propionic acid on fermentation quality and aerobic stability of total mixed ration silage prepared with whole-plant corn in Tibet. Asian Australas. J. Anim. Sci., 27(3): 349-356.

14. Salawu, M.B., Warren, E.H. and Adesogan, AT. (2001) Fermentation characteristics, aerobic stability and ruminal degradation of ensiled pea/wheat bi-crop forages treated with two microbial inoculants, formic acid or quebracho tannins. J. Sci. Food Agric., 81(13): 1263-1268.

15. Guo, X.S., Ding, W.R., Han, J.G. and Zhou, H. (2008) Characterization of protein fractions and amino acids in ensiled alfalfa treated with different chemical additives. Anim. Feed Sci. Technol., 142(1): 89-98.

16. Theodorou, M.K., Williams, B.A., Dhanoa, M.S., McAllan, A.B. and France, J. (1994) A simple gas production method using a pressure transducer to determine the fermentation kinetics of ruminant feeds. Anim. Feed Sci. Technol., 48(3-4): 185-197.

17. AOAC. (2005) Official Methods of Analysis. $18^{\text {th }}$ ed. AOAC International, Arlington, VA, USA.

18. Van Soest, P.J., Robertson, J.B. and Lewis, B.A. (1991) Methods for dietary fiber, neutral detergent fiber, and nonstarch polysaccharides in relation to animal nutrition. $J$. Dairy Sci., 74(10): 3583-3597.

19. Jayanegara, A., Dewi, S.P., Laylli, N., Laconi, E.B., Nahrowi, N. and Ridla, M. (2016) Determination of cell wall protein from selected feedstuffs and its relationship with ruminal protein digestibility in vitro. Media Peternakan, 39(2): 134-140.

20. Salminem, S. and Wright, A.V. (1998) Lactic Acid Bacteria: Microbiology and Functional Aspects. $2^{\text {nd }}$ ed. Marcell Dekker Inc., New York.

21. Wang, S., Kreuzer, M., Braun, U. and Schwarm, A. (2017) Effect of unconventional oilseeds (safflower, poppy, hemp, camelina) on in vitro ruminal methane production and fermentation. J. Sci. Food Agric., 97(11): 3864-3870.

22. Tilley, J.M.A. and Terry, R.A. (1963) A two-stage technique for the in vitro digestion of forage crops. Grass Forage Sci., 18(2): 104-111.

23. Uddin, M.K., Kondo, M., Kita, J., Matsui, H., Karita, S. and Goto, M. (2010) Effect of supplementation of soy sauce cake and vinegar brewer's cake with total mixed ration silage-based diet on nutrient utilization by Holstein steers. J. Food Agric. Environ., 8(3/4): 282-287.

24. Yasuda, K., Kitagawa, M., Oishi, K., Hirooka, H., Tamura, T. and Kumagai, H. (2016) Growth performance, carcass traits, physiochemical characteristics and intramuscular fatty acid composition of finishing Japanese black steers fed soybean curd residue and soy sauce cake. Anim. Sci. J., 87(7): 885-895.

25. McDonald, P., Henderson, A.R. and Heron, S.J.E. (1991) The Biochemistry of Silage. $2^{\text {nd }}$ ed. Chalcombe Publications, Marlow, UK.

26. Kholif, A.E., Gouda, G.A., Morsy, T.A., Salem, A.Z.M., Lopez, S. and Kholif, A.M. (2015) Moringa oleifera Leaf meal as a protein source in lactating goat's diets: Feed intake, digestibility, ruminal fermentation, milk yield and composition, and its fatty acids profile. Small Rumin Res., 129: 129-137.

27. Suharlina, S., Astuti D.A., Nahrowi, N., Jayanegara, A. and Abdullah, L. (2016) Nutritional evaluation of dairy goat rations containing Indigofera zollingeriana by using in vitro rumen fermentation technique (RUSITEC). Int. J. Dairy Sci., 11(3): 100-105.

28. Adesogan, A.T. and Salawu, M.B. (2002) The effect of different additives on the fermentation quality, aerobic stability and in vitro digestibility of pea/wheat bi-crop silages containing contrasting pea to wheat ratios. Grass Forage Sci., 57(1): 25-32.

29. Deaville, E.R., Givens, D.I. and Mueller-Harvey, I. (2010) Chestnut and mimosa tannin silages: Effects in sheep differ for apparent digestibility, nitrogen utilisation and losses. Anim. Feed Sci. Technol., 157(3-4): 129-138.

30. Oladosu, Y., Rafii, M.Y., Abdullah, N., Magaji, U., Hussin, G., Ramli, A. and Miah, G. (2016) Fermentation quality and additives: A case of rice straw silage. Biomed. Res. Int., 2016: 7985167.

31. Jonsson, A. (1991) Growth of Clostridium tyrobutyricum during fermentation and aerobic deterioration of grass silage. J. Sci. Food Agric., 54(4): 557-568.

32. Chaikong, C., Saenthaweesuk, N., Sadtagid, D., Intapim, A. and Khotakham, O. (2017) Local silage additive supplementation on fermentation efficiency and chemical components of leucaena silage. Livest. Res. Rural Dev., 29(6): 114.

33. Hapsari, S.S., Suryahadi, S. and Sukria, H.A. (2016) Improvement on the nutritive quality of napier grass silage through inoculation of Lactobacillus plantarum and formic acid. Media Peternakan, 39(2): 125-133.

34. González, L.A., Hoedtke, S., Castro, A. and Zeyner, A. (2012) Assessment of in vitro ensilability of jack bean (Canavalia ensiformis) and cowpea (Vigna unguiculata) grains, sole or mixed with sorghum (Sorghum bicolor) grains. Cuban J. Agric. Sci., 46(1): 55-62.

35. Silanikove, N., Perevolotsky, A. and Provenza, F.D. (2001) Use of tannin-binding chemicals to assay for tannins and their negative postingestive effects in ruminants. Anim. Feed Sci. Technol., 91(1-2): 69-81.

36. Ding, W., Guo, X. and Ataku, K. (2013) Characterization of peptides in ensiled alfalfa treated with different chemical additives. Anim. Sci. J., 84(12): 774-781.

37. Archimède, H., Sauvant, D. and Schmidely, P. (1997) Quantitative review of ruminal and total tract digestion of mixed diet organic matter and carbohydrates. Reprod. Nutr. Dev., 37(2): 173-189.

38. McDonald, P.P., Edwards, R., Greenhalgh, J., Morgan, C., Sinclair, L. and Wilkinson, R. (2011). Animal Nutrition. $7^{\text {th }}$ ed. Prentice Hall, New York, USA.

39. Rook, J.A.F. (1964) Ruminal volatile fatty acid production in relation to animal production from grass. Proc. Nutr. Soc., 23(1): 71-80.

40. Makkar, H.P.S., Blümmel, M. and Becker, K. (1995) Formation of complexes between polyvinyl pyrrolidones or polyethylene glycols and tannins, and their implication in gas production and true digestibility in in vitro techniques. Br. J. Nutr., 73(6): 897-913.

41. Makkar, H.P.S., Tran, G., Heuzé, V., Giger-Reverdin, S., Lessire, M., Lebas, F. and Ankers, P. (2016) Seaweeds for livestock diets: A review. Anim. Feed Sci. Technol., 212: 1-17.

42. European Food Safety Authority. (2014) Scientific opinion on the safety and efficacy of tannic acid when used as feed flavouring for all animal species. EFSA J., 12(10): 1-18.

43. Frutos, P., Hervás, G., Giráldez, F.J. and Mantecón, A. (2004) An in vitro study on the ability of polyethylene glycol to inhibit the effect of quebracho tannins and tannic acid on rumen fermentation in sheep, goats, cows, and deer. Aust. J. Agric. Res., 55(11): 1125-1132.

44. Jayanegara, A., Togtokhbayar, N., Makkar, H.P.S. and Becker, K. (2009) Tannins determined by various methods as predictors of methane production reduction potential of plants by an in vitro rumen fermentation system. Anim. Feed Sci. Technol., 150(3-4): 230-237.

45. Sebata, A., Ndlovu, L.R. and Dube, J.S. (2011) Chemical composition, in vitro dry matter digestibility and in vitro gas production of five woody species browsed by Matebele goats (Capra hircus L.) in a semi-arid savanna, Zimbabwe. Anim. Feed Sci. Technol., 170(1-2): 122-125. 
46. Huyen, N.T., Fryganas, C., Uittenbogaard, G., MuellerHarvey, I., Verstegen, M.W.A., Hendriks, W.H. and Pellikaan, W.F. (2016) Structural features of condensed tannins affect in vitro ruminal methane production and fermentation characteristics. J. Agric. Sci., 154(8): 1474-1487.

47. Jolazadeh, A.R., Dehghan-Banadaky, M. and Rezayazdi, K. (2015) Effects of soybean meal treated with tannins extracted from pistachio hulls on performance, ruminal fermentation, blood metabolites and nutrient digestion of Holstein bulls. Anim. Feed Sci. Technol., 203: 33-40.

48. Getachew, G., Blümmel, M., Makkar, H.P.S. and Becker, K.
(1998) In vitro gas measuring techniques for assessment of nutritional quality of feeds: A review. Anim. Feed Sci. Technol., 72: 261-281.

49. Krieg, J., Seifried, N., Steingass, H. and Rodehutscord, M. (2017) In situ and in vitro ruminal starch degradation of grains from different rye, triticale and barley genotypes. Animal, 11(10): 1745-1753.

50. Jayanegara, A., Kreuzer, M. and Leiber, F. (2012) Ruminal disappearance of polyunsaturated fatty acids and appearance of biohydrogenation products when incubating linseed oil with alpine forage plant species in vitro. Livest. Sci., 147(1-3): 104-112.

$* * * * * * * *$ 